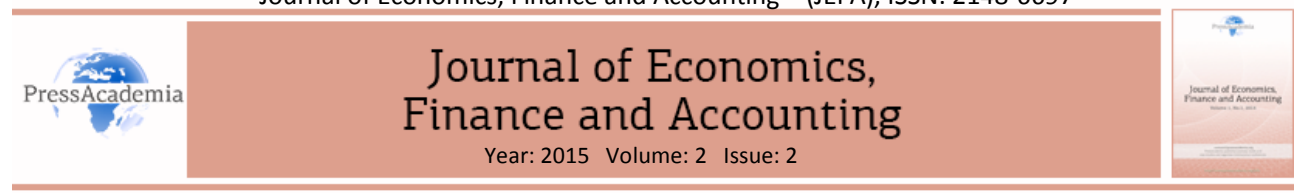

\title{
THE IMPACT OF EQUITY INDEX FUTURES TRADING ON THE UNDERLYING INDEX VOLATILITY: EVIDENCE FOR THE ISE-30 STOCK INDEX FUTURES CONTRACT
}

\section{DOI: 10.17261/Pressacademia.2015211517}

\author{
Hakan Er', Muhammad Wissam Al-Masri², Kokou Adalessossi ${ }^{3}$ \\ ${ }^{1}$ Akdeniz University. erhakan@akdeniz.edu.tr \\ ${ }^{2}$ Akdeniz University, almasri.wissam@gmail.com \\ ${ }^{3}$ Akdeniz University, pascaladalessossi@yahoo.fr
}

\section{Keywords \\ Futures; Volatility; Expiration Effect; Istanbul Stock Exchange, TurkDEX}

JEL Classification G13, G14, G15

\begin{abstract}
The issue that futures-trading activity may result in excessive equity volatility has attracted much attention, both academic and regulatory. Many academicians have claimed that the introduction of the futures contracts will lead to an increase in the spot market volatility and destabilize the equity prices. This has also been an important concern for regulators. Many others have argued the contrary and claimed that futures trading will have stabilizing effects on spot prices. There is no theoretical answer that will resolve this debate; proper empirical investigation will give insights on this effect. Many previous empirical studies deal with the developed markets, especially with the US. The number of studies employing emerging market data is quite limited and there are only a handful of studies dealing with the Turkish market. In this study we examine the effect of futures trading on index volatility using the data from an important emerging market: Turkey. Using the Istanbul Stock Exchange 30 (ISE 30) Index data between February 2005 and April 2015, we test the hypothesis that the variance of daily returns in the futures expiration period ( 9 days before the expiration of the futures contract) is greater than the variance of index returns in the pre-expiration period (10-50 days prior to futures expiration date). The results of the study show that expiration period variance is not greater than pre-expiration variance.
\end{abstract}

\section{INTRODUCTION}

One of the major concerns of many practitioners, academicians and regulators is that the futures trading may have destabilizing effects on the underlying spot markets. The public's perception of the effects of futures trading on spot markets is that futures trading provokes volatility in spot markets through excessive, irrational speculative activity by uninformed traders. The critics of the futures trading activity argue that order flow imbalances caused by these uninformed traders result in higher spot volatility, which in turn raises the risk premium demanded by investors. As a consequence, both real interest rates and cost of capital increase. This increase results in a decrease in the value of investors' assets and reduce the level their wealth. Thus, as a result of the higher volatility in asset prices, investors lose confidence in stock markets. 
This view was justified by the events like October 1987 crash which took place soon after the index futures contracts introduced. As Edwards (1988a) pointed out: "Whenever high market volatility occurs, the tendency seems to be to blame it on whatever new is going on at the time." Many associated excessive volatility in the spot market during the crash period with the speculative trading of the index futures and options, and called for limits on derivatives trading activity. Some even recommended abolition of derivatives trading completely.

Program trading strategies like index arbitrage and portfolio insurance have also been blamed for the increased volatility in spot markets. Arbitrageurs unwind their spot positions at the expiration days of futures or options contracts. The arbitrageurs' orders to unwind their positions may result in trades that are predominantly one sided, which may in turn create order imbalances in spot markets. On days other than the expiration days, portfolio insurance activities may cause excessive buying or selling in both spot and futures markets when spot index reaches a predetermined level. If the participants of the markets (especially the specialists) fail to anticipate this excessive trading activity, order imbalances may arise again, destabilize the market and increase volatility.

Critics of the view that derivatives destabilize spot markets underline the economic benefits of derivatives trading such as increased market depth (Danthine, 1978), increased interaction and greater risk sharing between speculators and hedgers (Stein, 1987), and better and faster dissemination of market wide information (Froot and Perold, 1991). Increased market depth and greater risk sharing are argued to result in lower spot market volatility. Increased flow of information should result in a change in spot volatility (Cox, 1976). Ross (1989) argues that, in a market in which arbitrage opportunities do not exist, the volatility of the spot price should change as a result of the increased flow of information provided by the trading of the derivatives. Although no explanation is provided by the proponents of this view about the size and direction of volatility changes, it is stressed that increase in volatility is not essentially detrimental to the financial system. Increased volatility may simply be the result of the changes in fundamental economic factors, or information and expectations about those changes. Therefore, no undesirable effect is associated with derivatives trading activity. By facilitating rapid flow of information, futures trading may indeed enhance market efficiency as the rate at which the information is impounded into prices improves.

As the theoretical debate on the impact of derivative trading on spot volatility has remained unresolved, the relationship between futures trading and spot market volatility has attracted ample empirical attention in the financial literature. A great deal of empirical research has been conducted on commodity futures. Following the introduction of financial futures, an extant literature on the impact of financial futures on the spot market volatility has quickly developed. Vast majority of empirical research in the literature focused on developed markets (especially the USA). Empirical research on emerging markets, on the other hand, is still limited as the majority of derivatives markets in emerging countries are still in their infancy compared to developed markets. Emerging markets are characterized by thin (or infrequent) trading and likely to suffer more from over-speculation. Therefore, emerging markets are best places to analyze whether derivatives have destabilizing effects on spot markets. 
Turkish Derivatives Exchange (TurkDEX) was founded in 2003 and trading in futures started in February 2005. According to Futures Industry Association Annual Volume survey, TurkDEX ranked 30th derivatives Exchange with the $62,474,464$ contracts traded in 2012. The number of empirical studies that employed Turkish data to analyze impact of futures trading on spot market is still quite limited. Moreover, we are not aware of any study that analyzes the effect that settlement of futures contracts has on the underlying market (the expiration effect). This study attempts to contribute to the literature by analyzing expiration effect in Turkish market. To this end, we use Istanbul Stock Exchange 30 (ISE 30) Index data to test the hypothesis that the variance of daily returns in the futures expiration period (up to 9 days before the expiration of the futures contract) is greater than the variance of index returns in the pre-expiration period (10-60 days prior to futures expiration date).

The rest of the paper is organized as follows. Section II briefly reviews the literature on the impact of futures trading on spot volatility. Section III describes methodology and data. Results are set out in Section IV and final section provides a summary, conclusions and suggestions for future work.

\section{LITERATURE SURVEY}

One line of research on the impact of futures trading on the volatility of the spot market focused on whether stock index futures trading poses a long-run threat to market stability. To this end, a pre-futures (the period before the introduction of futures contracts) and a post-futures (the period after the introduction of futures contracts) period for the market under study and an index representing that market are defined. A measure of volatility for returns of that index is then chosen. Some early studies simply use variance or standard deviation of the close-to-close returns; while others use measures like efficient high-low variance estimator, intraday price range estimator, etc. Several of these studies simply compare pre and post-futures period volatility using simple statistical tests. More recent studies generally employ GARCH family of techniques to calculate volatility. A proxy variable which is assumed to be unaffected by the introduction of futures is also defined to remove market-wide influences on price changes. Spot market volatility is then regressed against the proxy variable and a dummy variable which takes on the value of 0 for the pre-futures and 1 for the past-futures period. If this dummy variable is statistically significant then it is concluded that futures trading has an impact on spot volatility. The results of the empirical studies analyzing the long-run impacts of futures trading on spot volatility are mixed.

Santoni (1987) analyzes the S\&P 500 index volatility after the introduction of index futures and reports no statistically significant changes in spot volatility. Edwards (1988a) and Edwards (1998b) studies the effect on S \& P 500 and Value Line Index and concludes that S \& P 500 volatility has decreased after the introduction of futures, however, there has been no significant difference in Value Line Index volatility. Grossman (1988) analyzes the relationship between program trading intensity and New York Stock Exchange (NYSE) volatility and finds no significant correlation. 
Aggarwal (1998) reports increased volatility for post-futures period, however, argues that this increase cannot be associated with the introduction of futures contracts as the volatility of markets in which no futures contracts are traded has also increased in this period.

Lee and Ohk (1992) analyzes Australia, Hong Kong, Japan, the UK and the US market volatility after the introduction of index futures trading in each country using daily index data. They report increased volatility for Japan, the UK and the US. However, they report decreased volatility for Hong Kong and no significant change for Australia. Antoniou and Holmes (1995) report an increase in London Stock Exchange volatility after the introduction of FTSE-100 index futures contract. However, Antoniou et al. (1998) reports no significant in UK spot volatility. In this study, they analyze the spot volatility of Germany, Japan, Spain, Switzerland, the U.K and the US for the post-futures period and find statistically significant negative effect for Germany and Switzerland. For the other countries in the sample they report no significant change in spot volatility.

Bologna and Cavallo (2002) study on Italian stock market reports a decrease for the MIB30 index volatility. Similarly, Pilar and Rafael (2002) study on Spanish stock market reports decreased volatility for Ibex35 index.

Results of empirical studies on emerging countries are also mixed. Drimbetas et al. (2007) study on Greek stock market also reports reduction in the volatility of the spot market. Four studies on Turkish stock market (Istanbul Stock Exchange), Baklaci and Tutek (2006), Kasman and Kasman (2008), Caglayan (2006) and Caglayan (2015) report decreased spot market volatility for the post-futures period. Ryoo and Smith (2004) study on Korean market and Pok and Poshakwale (2004) study on Malaysian stock market, on the other hand, report increased spot volatility for the post-futures periods.

No consensus on the impact of futures trading on spot volatility seems to emerge from the results of these studies. Results vary depending on the time period and the country studied.

The other line of research has attempted to explore the effect that the settlement of derivatives contracts have on the underlying market volatility. This line of empirical research focused on the "Expiration Effect" (behavior of the volatility of the underlying asset as the maturity of the futures approaches). Although the expiration effect is short lived, it has important implications for the margins required by the clearing houses, the price limits, hedging strategies and the valuation of options.

Stoll and Whaley (1997) argue that expiration effects arise from a combination four factors: index arbitrage opportunities, the cash settlement feature of the index derivatives, the stock market procedures for unwinding of arbitrage positions, and attempts to manipulate prices. When the index futures price deviates from the theoretical futures price, arbitrageurs take long or short positions in the futures depending on the direction of mispricing and take an opposite position in index stocks to lock-in an arbitrage profit. At the expiration of the futures contract, thanks to the cash-settlement, futures position self-liquidates. However, stocks should be liquidated through trades in the stock market. If the stock market mechanisms are not well defined to offset sudden imbalances arising from the unwinding of large arbitrage positions, significant price effects may occur. 
Moreover, some arbitrageurs may quietly sell a portion of stocks prior to expiration and use the remaining stocks to manipulate the level of the index underlying the futures contract. If they can drive the index down, they face a much lower settlement price make a profit futures position that is higher than it would be.

Majority of the empirical studies on the effect that the settlement of futures contracts have on the underlying market volatility focused on the spot volatility on the expiration day, or expiration hour ${ }^{1}$. Stoll and Whaley (1987) study on US market reports significantly higher volatility on the expiration days of the futures contracts. Other studies reporting similar results on US market are Herbst and Maberly (1990), Hancock (1993), and Chen and Williams (1994). Chamberlain, Cheung, and Kwan (1989) report higher volatility during the expiration period for Toronto Stock Exchange, Pope and Yadav (1992) for the UK, Swidler, Schwartz, and Kristiansen (1994) for the Oslo Stock Exchange, Karolyi (1996) for Japanese Stock Exchange. Kan (2001) study on Hong Kong stock market, Chow et al. (2003) study on Hong Kong stock market, Nel and Kruger (2001) study on South African stock exchange, on the other hand, report no significant increase in market volatility during the expiration period.

Again, the results are mixed. The literature review reveals that more studies analyzing the impact of manipulation which is described by Stoll and Whaley (1997) as the fourth possible cause of increased spot volatility during expiration are needed. If index futures arbitrageurs are quietly selling a portion of stocks long before the expiration futures contracts and using the remaining stocks to manipulate the level of the index underlying the futures contract, the spot volatility of market will increase during this period. Turkish market is a thinly traded market like the markets of many other emerging countries. It is easier to manipulate prices in a thinly traded market. Turkish market is one of the best places to analyze this aspect of the expiration effect. To our best knowledge, no empirical study on focusing this aspect of the expiration on Turkish market exists. This is where this study attempts to contribute the literature.

\section{DATA AND METHODOLOGY}

As mentioned in the literature review section, Stoll and Whaley (1997) suggest four possible factors for the increased spot volatility during the expiration period. The first three factors (index arbitrage opportunities, the cash settlement feature of the index derivatives, the stock market procedures for unwinding of arbitrage positions) should account for the increased volatility on the expiration day or in the last hour of trading on the expiration day. However, the fourth factor, manipulation, should have an impact on the spot volatility on a period much longer than expiration day. Manipulators should sell a portion of the stocks related to their index arbitrage positions through program trade long before the delivery and start forcefully selling the remaining stocks days before the delivery date to be able to effectively drive the prices down.

\footnotetext{
${ }^{1}$ There is an extensive literature on the "triple-witching hour", the final hour of trading on days when index futures, index options and individual stock options expire simultaneously.
} 
Therefore, comparing the spot volatility on the expiration day with the volatility of the previous day(s) will not provide insights into the impact of manipulation on the spot volatility. In this study, we define expiration period for each futures contract as the last nine trading days (including the expiration day) trading period for that contract. Preexpiration period for each contract starts from a day after the expiration of the previous contract and ends when the expiration period begins.

We analyze the expiration period effects of 61 Istanbul Stock Exchange 30 Index (ISE-30) Futures contracts during the period February 2005 through April 2015. We use daily ISE-30 data for the analysis. The data used in this study was provided by Istanbul Stock Exchange. Trading in ISE 30 index futures started on the TURKDEX on February 4, 2005. TurkDEX has a fully electronic trading system which allows remote access. The contract has six delivery months: February, April, June, August, October and December. The contract is settled by cash at the Exchange Delivery Settlement Price (EDSP). EDSP is based on the average level of the ISE 30 Index in the last thirty minutes of trading on the Last Trading Day. Table 1 below summarizes contract specifications:

Table 1: ISE 100 Index Futures Contracts

\begin{tabular}{|l|l|}
\hline Underlying Asset & ISE 30 Index \\
\hline Contract Size & $\begin{array}{l}\text { Value calculated by dividing the index value by } 1000 \text { and } \\
\text { multplying the quotient by TRY } 100 \text { (ISE 100 index } \\
/ 1000) * 100\end{array}$ \\
\hline Minimum Price Tick & Price tick is 0.025 which corresponds to TRY 2.5 \\
\hline Contract Months & $\begin{array}{l}\text { February, April, June, August, December (Contracts with } \\
\text { two different expiration months to nearest to the current } \\
\text { month shall be traded concurently ) }\end{array}$ \\
\hline Settlement Method & Cash Settement \\
\hline Expiry date & $\begin{array}{l}\text { Last business day of each contract month. In case domestic } \\
\text { markets are closed for half day due to an official holiday, } \\
\text { expiry date shall be the preceding business day. }\end{array}$ \\
\hline Last Trading Day & $\begin{array}{l}\text { Last business day of each contract month. In case domestic } \\
\text { markets are closed for half day due to an official holiday, } \\
\text { expiry date shall be the preceding business day. }\end{array}$ \\
\hline
\end{tabular}

Two estimators of volatility is used to examine market volatility: the standard close-toclose daily price variance and an efficient high-low variance estimator.

Annualized close-to-close volatility estimator is calculated using the following formula:

$$
\sigma_{C C}=\sqrt{252 \cdot \frac{1}{n} \cdot \sum_{i=1}^{n} r_{i}^{2}}
$$


Here, $\sigma_{\mathrm{CC}}$ is the close-to-close volatility estimator, $\mathrm{n}$ is the number of observations in expiration or pre-expiration period and $r_{i}$ is the first differences of the natural log of daily prices. Board and Sutcliffe (1990) argue that as the level of prices alters over time, the variance of the logarithm of the price relatives is more likely to be stationary than is the variance of the alternatives. This advantage dictated our choice on of the calculation of daily returns.

As it is often alleged that much of the volatility is due to intraday price movements, an estimator which accounts for these movements is also used. Parkinson's "efficient highlow variance estimator" is proven theoretically to be more efficient than close-close variance estimator (under certain restrictive assumptions) and is widely accepted by the market practitioners. This estimator is calculated using the following formula:

$$
\sigma_{H L}=\sqrt{\frac{1}{4 \cdot \ln 2} \cdot \frac{252}{n} \cdot \sum_{i=1}^{n} \ln \left(\frac{H_{i}}{L_{i}}\right)^{2}}
$$

Here, $\sigma_{\mathrm{HL}}$ is the efficient high-low volatility estimator, $\mathrm{n}$ is the number of observations in expiration or pre-expiration period, $\mathrm{H}_{\mathrm{i}}$ and $\mathrm{L}_{\mathrm{i}}$ are the highest and lowest prices on trading day i.

To determine whether expiration effects exist, we compare the volatility of each futures maturity's expiration and pre-expiration period by means of an F-test. We test the null hypothesis $H_{0}: \sigma_{\mathrm{e}}{ }^{2} \leq \sigma_{\mathrm{p}}{ }^{2}$, where $\sigma_{\mathrm{e}}{ }^{2}$ and $\sigma_{\mathrm{p}}{ }^{2}$ are variances in expiration and pre-expiration period, respectively. F-statistic is calculated by dividing $\sigma_{\mathrm{e}}{ }^{2}$ by $\sigma_{\mathrm{p}}{ }^{2}$. The calculated F-statistic has $n_{e}-1$ and $n_{p}-1$ degrees of freedom. Here, $n_{e}$ is the number of observations in the expiration period and $n_{p}$ is the number of observations in the pre-expiration period. If the calculated F-statistic is greater that the critical F-value at $5 \%$ significance level null is rejected and it is concluded that expiration variance is not statistically different than preexpiration variance.

\section{EMPIRICAL FINDINGS}

The results of the F-test are presented in Table 2. When close-to-close estimator is used for the calculation of volatility, 14 periods' null hypotheses rejected. June and December 2005; August and December 2006; February, April and December 2008; April, June and December 2010; April 2011, December 2012, October 2013 and December 2014 expiration periods' volatilities are significantly higher than pre-expiration periods' volatilities. There are six December expiration periods in which volatilities are higher than the pre-expiration period volatilities. This result might be associated with the January (Turn-of-the-Year) effect. At the turn-of-the-year (starting from December 15) investors start selling stocks that have declined in price to realize tax losses. Professional investors start selling embarrassing losers for end-of-year "window dressing". Investors buy back the stocks they sold during the first ten of days of January. 
The number of expiration periods for which the null hypotheses rejected goes down to 5 when high-low estimator is used. These periods are October 2006, June 2016, June, August and December 2013. This result shows that empirical conclusions on expiration effect are sensitive to the volatility measure chosen. Another conclusion that can be drawn from this result is that methods that uncover the complex intraday volatility dynamics might give more insights into this effect.

Table 2: F-Tests for the Expiration Effect

\begin{tabular}{|c|c|c|c|c|c|c|c|}
\hline \multirow[b]{2}{*}{$\begin{array}{l}\text { Delivery } \\
\text { Date }\end{array}$} & \multicolumn{3}{|c|}{ Close-to-Close Volatility } & \multicolumn{3}{|c|}{ High-Low Volatility Estimator } & \multirow[b]{2}{*}{$\begin{array}{l}\text { Critical } \\
\text { F-score }\end{array}$} \\
\hline & $\begin{array}{l}\text { Pre-Expiration } \\
\text { Period }\end{array}$ & $\begin{array}{l}\text { Expiration } \\
\text { Period }\end{array}$ & \begin{tabular}{|c|} 
Computed \\
statistic
\end{tabular} & $\begin{array}{l}\text { Pre-Expiration } \\
\text { Period }\end{array}$ & $\begin{array}{c}\text { Expiration } \\
\text { Period } \\
\end{array}$ & $\begin{array}{l}\text { Computed } \\
\text { F-statistic }\end{array}$ & \\
\hline $29 / 04 / 2005$ & 0.02144558 & 0.01704282 & 1.58340610 & 0.01932692 & 0.01595545 & 0.77760292 & 2.16 \\
\hline $30 / 06 / 2005$ & 0.01535140 & 0.00854394 & $3.22834212 *$ & 0.01334128 & 0.01081867 & 0.41013026 & 2.17 \\
\hline $31 / 08 / 2005$ & 0.01182065 & 0.01516817 & 0.60731814 & 0.01148722 & 0.01161693 & 1.74355915 & 2.17 \\
\hline $31 / 10 / 2005$ & 0.01861705 & 0.01702789 & 1.19536349 & 0.01706762 & 0.01660731 & 0.99534985 & 2.17 \\
\hline $30 / 12 / 2005$ & 0.01518970 & 0.00936255 & $2.63214765^{*}$ & 0.01380009 & 0.00888235 & 0.46028214 & 2.18 \\
\hline $28 / 02 / 2006$ & 0.01864325 & 0.01790501 & 1.08416123 & 0.01732253 & 0.01534826 & 1.06838170 & 2.24 \\
\hline $28 / 04 / 2006$ & 0.01948615 & 0.01783830 & 1.19328762 & 0.01856995 & 0.01770024 & 0.92275336 & 2.17 \\
\hline $30 / 06 / 2006$ & 0.02769308 & 0.02547193 & 1.18200425 & 0.02414501 & 0.02672416 & 1.11293223 & 2.16 \\
\hline $31 / 08 / 2006$ & 0.02018346 & 0.00859908 & $5.50918292 *$ & 0.01745524 & 0.01055198 & 0.24269042 & 2.17 \\
\hline $31 / 10 / 2006$ & 0.01222712 & 0.01783901 & 0.46979284 & 0.01164361 & 0.01482245 & $2.34728918^{*}$ & 2.21 \\
\hline $29 / 12 / 2006$ & 0.01607103 & 0.00929967 & $2.98642880^{*}$ & 0.01330262 & 0.01013738 & 0.48872098 & 2.17 \\
\hline $28 / 02 / 2007$ & 0.01601440 & 0.02208994 & 0.52557182 & 0.01440183 & 0.01815596 & 2.35263105 & 2.20 \\
\hline $30 / 04 / 2007$ & 0.01690002 & 0.02164865 & 0.60941472 & 0.01505482 & 0.02362315 & 2.06780909 & 2.18 \\
\hline $29 / 06 / 2007$ & 0.01300171 & 0.01491727 & 0.75966504 & 0.01306887 & 0.01186447 & 1.30287532 & 2.16 \\
\hline $31 / 08 / 2007$ & 0.02815132 & 0.02464196 & 1.30510954 & 0.02332374 & 0.01842323 & 1.11623149 & 2.16 \\
\hline $31 / 10 / 2007$ & 0.01918096 & 0.02125187 & 0.81460357 & 0.01627777 & 0.02126910 & 1.70452972 & 2.19 \\
\hline $31 / 12 / 2007$ & 0.01707759 & 0.01513419 & 1.27331132 & 0.01671438 & 0.01260188 & 0.81985642 & 2.19 \\
\hline $29 / 02 / 2008$ & 0.03005728 & 0.01712739 & $3.07975883^{*}$ & 0.02592418 & 0.01807519 & 0.43648821 & 2.17 \\
\hline $30 / 04 / 2008$ & 0.02673901 & 0.01287005 & $4.31648657^{*}$ & 0.02373036 & 0.01455153 & 0.29413835 & 2.18 \\
\hline $30 / 06 / 2008$ & 0.01568720 & 0.01697681 & 0.85384444 & 0.01508983 & 0.01636046 & 1.26573792 & 2.18 \\
\hline $29 / 08 / 2008$ & 0.02518380 & 0.01934841 & 1.69415004 & 0.02252066 & 0.01661675 & 0.73812222 & 2.16 \\
\hline $31 / 10 / 2008$ & 0.04471222 & 0.04188248 & 1.13969234 & 772430 & 1904 & 1.23260090 & 2.19 \\
\hline $31 / 12 / 2008$ & 0.03872687 & 0.00976849 & $15.71700718^{*}$ & 0.03096690 & 0.01403875 & 0.09950835 & 2.21 \\
\hline $27 / 02 / 2009$ & 0.02679816 & 0.02248680 & 1.42021683 & 0.02168858 & 0.02046162 & 1.07496243 & 2.19 \\
\hline $30 / 04 / 2009$ & 0.02045356 & 0.02652563 & 0.59457436 & 0.01834926 & 0.02051645 & 2.08975134 & 2.17 \\
\hline $30 / 06 / 2009$ & 0.01776576 & 0.01808043 & 0.96549508 & 0.01862345 & 0.01630050 & 0.94253536 & 2.19 \\
\hline $31 / 08 / 2009$ & 0.01672277 & 0.01918812 & 0.75954131 & 0.01716822 & 0.01648358 & 1.24914939 & 2.16 \\
\hline $30 / 10 / 2009$ & 0.01617742 & 0.01817060 & 0.79264727 & 0.01532308 & 0.01835797 & 1.40619894 & 2.19 \\
\hline $31 / 12 / 2009$ & 0.01589970 & 0.01199080 & 1.75825389 & 0.01596589 & 0.01111001 & 0.56404018 & 2.16 \\
\hline $24 / 02 / 2010$ & 0.01495142 & 0.01978722 & 0.57094653 & 0.01480748 & 0.01978037 & 1.78569575 & 2.22 \\
\hline $30 / 04 / 2010$ & 0.01475047 & 0.00954104 & 2.39012383* & 0.01371956 & 0.01335896 & 0.48362750 & 2.14 \\
\hline $30 / 06 / 2010$ & 0.02410469 & 0.01207075 & $3.98781374 *$ & 37382 & 0.01293993 & 0.38818401 & 2.18 \\
\hline $31 / 08 / 2010$ & 0.01144134 & 0.00781155 & 2.14525470 & 0.01224481 & 0.01046092 & 0.40697735 & 2.17 \\
\hline $27 / 10 / 2010$ & 0.01111319 & 0.01420102 & 0.61240488 & 0.01150140 & 0.01397026 & 1.52453511 & 2.21 \\
\hline $31 / 12 / 2010$ & 0.01738522 & 0.01046576 & $2.75942907^{*}$ & 0.01624538 & 0.00968573 & 0.41503228 & 2.16 \\
\hline $28 / 02 / 2011$ & 0.01403436 & 0.01596521 & 0.77274462 & 0.01307982 & 0.01330959 & 1.48986117 & 2.19 \\
\hline
\end{tabular}

Note: ${ }^{*}=$ statistically significant 
Table 2: F-Tests for the Expiration Effect (Continued)

\begin{tabular}{|c|c|c|c|c|c|c|c|}
\hline \multirow[b]{2}{*}{$\begin{array}{l}\text { Delivery } \\
\text { Date }\end{array}$} & \multicolumn{3}{|c|}{ Close-to-Close Volatility } & \multicolumn{3}{|c|}{ High-Low Volatility Estimator } & \multirow[b]{2}{*}{$\begin{array}{l}\text { Critical } \\
\text { F-score }\end{array}$} \\
\hline & $\begin{array}{c}\text { Pre-Expiration } \\
\text { Period }\end{array}$ & $\begin{array}{l}\text { Expiration } \\
\text { Period }\end{array}$ & $\begin{array}{l}\text { Computed } \\
\text { F-statistic }\end{array}$ & $\begin{array}{c}\text { Pre-Expiration } \\
\text { Period }\end{array}$ & $\begin{array}{c}\text { Expiration } \\
\text { Period } \\
\end{array}$ & $\begin{array}{l}\text { Computed } \\
\text { F-statistic }\end{array}$ & \\
\hline 29/04/2011 & 0.01656174 & 0.00977964 & $2.86791338^{*}$ & 0.01482110 & 0.00954816 & 0.43539633 & 2.16 \\
\hline $30 / 06 / 2011$ & 0.01559422 & 0.01085974 & 2.06199922 & 0.01377601 & 0.01067788 & 0.62142980 & 2.17 \\
\hline $26 / 08 / 2011$ & 0.02386397 & 0.02108515 & 1.28094903 & 0.02270365 & 0.02439271 & 0.86250577 & 2.19 \\
\hline $31 / 10 / 2011$ & 0.02125686 & 0.02028910 & 1.09767217 & 0.01886572 & 0.01736856 & 1.15658880 & 2.17 \\
\hline $30 / 12 / 2011$ & 0.02020742 & 0.01503495 & 1.80641695 & 0.01740249 & 0.01363303 & 0.74641660 & 2.19 \\
\hline $29 / 02 / 2012$ & 0.01685858 & 0.01459974 & 1.33337298 & 0.01498667 & 0.01198489 & 0.94902982 & 2.17 \\
\hline $30 / 04 / 2012$ & 24507 & 5502 & 1.61266706 & 9119 & 0.01042956 & 0.75496932 & 2.18 \\
\hline $29 / 06 / 2012$ & 0.01009210 & 0.01661936 & 0.36875232 & 0.01052526 & 0.01214657 & $2.49323342 *$ & 2.17 \\
\hline $31 / 08 / 2012$ & 0.01204883 & 0.00899254 & 1.79524983 & 0.01057665 & 0.00821141 & 0.72288364 & 2.18 \\
\hline $31 / 10 / 2012$ & 0.00877850 & 0.00936489 & 0.87868901 & 0.00869142 & 0.00743845 & 1.16097745 & 2.21 \\
\hline $31 / 12 / 2012$ & 0.01053280 & 0.00553996 & $3.61471280 *$ & 0.00964816 & 0.00699118 & 0.32970429 & 2.17 \\
\hline $28 / 02 / 2013$ & 0.01564552 & 0.01320323 & 1.40416910 & 0.01335240 & 0.01267533 & 0.97778238 & 2.18 \\
\hline $30 / 04 / 2013$ & 0.01110293 & 0.00912587 & 1.48022148 & 0.00979004 & 0.00979146 & 0.86891929 & 2.18 \\
\hline $28 / 06 / 2013$ & 0.02850677 & 0.03211757 & 0.78779051 & 0.01864007 & 0.02067681 & 2.96886198* & 2.18 \\
\hline 29/ & 76 & 0 & 0 & 4 & 97 & $4 *$ & 2.18 \\
\hline $31 / 10 / 2013$ & 0.02135729 & 0.01437241 & $2.20817533^{*}$ & 0.01181176 & 0.00871416 & 1.48057339 & 2.21 \\
\hline $31 / 12 / 2013$ & 0.01748372 & 0.03115597 & 0.31490911 & 0.01352005 & 0.02515809 & $5.31038464 *$ & 2.17 \\
\hline $28 / 02 / 2014$ & 0.01666574 & 0.01566694 & 1.13156787 & 0.01644929 & 0.01030734 & 0.90714018 & 2.18 \\
\hline $30 / 04 / 2014$ & 0.01743784 & 0.01293402 & 1.81768232 & 0.01201332 & 0.01033337 & 1.15915495 & 2.18 \\
\hline $30 / 06 / 2014$ & 9430 & 0.00850867 & 2.05394984 & 1040578 & 0.00807458 & 0.66861252 & 2.19 \\
\hline $29 / 08 / 2014$ & 0.01176676 & 0.01216841 & 0.93507387 & 0.01156291 & 0.00935574 & 1.10747437 & 2.19 \\
\hline $31 / 10 / 2014$ & 0.01314521 & 0.01053022 & 1.55833066 & 053315 & 306 & 518 & 2.18 \\
\hline $31 / 12 / 2014$ & 0.01504987 & 0.00977234 & $2.37174766^{*}$ & 0.01203498 & 0.00859503 & 0.65933540 & 2.17 \\
\hline $27 / 02 / 2015$ & 0.01171098 & 0.01333743 & 0.77097793 & 0.01027150 & 0.01158930 & 1.68607460 & 2.19 \\
\hline $30 / 04 / 2015$ & 0.01520351 & 0.01472484 & 1.06607269 & 0.01244214 & 0.01144791 & 1.40059019 & 2.17 \\
\hline
\end{tabular}

*statistically significant

\section{CONCLUSION}

This study has examined the expiration effects of the ISE-30 futures on the Turkish stock market using daily data covering the period from February 2005 to April 2015. The comparison period approach is used to compare the return volatility on the expiration period with that of pre-expiration period. Two different volatility measures, close-to-close volatility estimator and an efficient high-low estimator, are used for comparison. The Ftests employed indicate that only 14 of the close-to-close and just 5 of the high-low volatilities of the expiration periods are greater than the pre-expiration period volatility. The results of the F-tests suggest that the expiration of ISE-30 index futures does not have effects on the return volatility on the underlying stock market. This finding is contrary to our assumption that expiration effects should be present in Turkish market, as it is a thinly traded market and as a consequence of thin trading, index futures arbitrage and manipulation related activities should have significant effects on stock market volatility. 
In future work this effect will be investigated by employing intra-day data and by using fractionally integrated GARCH variations that model realized volatility.

\section{REFERENCES}

Aggarwal, R. (1988). Stock index futures and cash market volatility. Review of Futures Markets, 7(2), $290-299$.

Antoniou, A., \& Holmes, P. (1995). Futures trading, information and spot price volatility: evidence for the FTSE100 stock index futures contract using GARCH. Journal of Banking \& Finance, 19(1), 117-129.

Antoniou, A., Holmes, P., \& Priestley, R. (1998). The Effects of Stock Index Futures Trading on Stock Index Volatility: An Analysis of the Asymmetric Response of Volatility to News (Digest Summary). Journal of Futures Markets, 18(2), 151-66.

Baklaci, H., \& Tutek, H. (2006). The impact of the futures market on spot volatility: An analysis in Turkish derivatives markets. Computational Finance and Its Applications II, 43, 237-246.

Board, J. and Sutcliffe, C. (1990). Information,volatility, volume, and maturity: An investigation of Stock Index Futures, Review of Futures Markets, 9(3), 533-547.

Bologna, P., \& Cavallo, L. (2002). Does the introduction of stock index futures effectively reduce stock market volatility? Is the'futures effect'immediate? Evidence from the Italian stock exchange using GARCH. Applied Financial Economics, 12(3), 183-192.

Caglayan, Ebru (2006), 'Index Futures and Spot Market Volatility: Evidence from Turkey. Working Paper Series 4/01, Westminster Service Sector Research Centre, University of Westminster, UK, ISBN 0-9552685-3-2, ISSN 1750-6336.

Caglayan, E. (2011). The impact of stock index futures on the Turkish spot market. Journal of Emerging Market Finance, 10(1), 73-91.

Chamberlain, T. W., Cheung, C. S., \& Kwan, C. C. (1989). Expiration-day effects of index futures and options: Some Canadian evidence. Financial Analysts Journal, 45(5), 67-71.

Chen, C., \& Williams, J. (1994). Triple - witching hour, the change in expiration timing, and stock market reaction. Journal of Futures Markets, 14(3), 275-292.

Chow, Y. F., Yung, H. H., \& Zhang, H. (2003). Expiration day effects: The case of Hong Kong. Journal of Futures Markets, 23(1), 67-86.

Cox, C. C. (1976). Futures trading and market information. The Journal of Political Economy, 1215-1237.

Danthine, J. P. (1978). Information, futures prices, and stabilizing speculation. Journal of Economic Theory, 17(1), 79-98.

Drimbetas, E., Sariannidis, N., \& Porfiris, N. (2007). The effect of derivatives trading on volatility of the underlying asset: evidence from the Greek stock market. Applied Financial Economics, 17(2), 139-148.

Edwards, F.R. (1988).Does futures trading increase Stock market volatility?, Financial Analysts Journal, 44(1) , 6369

Edwards, F.R. (1988). Futures trading and cash market volatility: stock index and interest rate futures, Journal of Futures Markets, 8(4), 421-439

Grossman, S.J. (1988). An analysis of the implications for stock and futures price volatility of program trading and dynamic hedging strategies, Journal of Business, Vol. 61, No. 3, pp.275-298.

Hancock, G. D. (1993). Whatever happened to the triple witching hour?. Financial Analysts Journal, 49(3), 66-72.

Herbst, A. F., \& Maberly, E. D. (1990). Stock index futures, expiration day volatility, and the "special" Friday opening: A note. Journal of Futures Markets, 10(3), 323-325.

Karolyi, G. A. (1996). Stock market volatility around expiration days in Japan. J. OF DERIVATIVES. 
Kasman, A., \& Kasman, S. (2008). The impact of futures trading on volatility of the underlying asset in the Turkish stock market. Physica A: Statistical Mechanics and its Applications, 387(12), 2837-2845.

Froot, K.A., and A.F. Perold, 1991, New trading practices and short-run market efficiency, WP MIT.

Kan, A. C. (2001). Expiration-day effect: evidence from high-frequency data in the Hong Kong stock market. Applied Financial Economics, 11(1), 107-118.

Lee, S. B., \& Ohk, K. Y. (1992). Stock index futures listing and structural change in time - varying volatility. Journal of Futures Markets, 12(5), 493-509.

Nel, I., \& de K Kruger, W. (2001). Equity index futures contracts and share price volatility: A South African perspective. Meditari Accountancy Research, 9(1), 217-229.

Pok, W. C., \& Poshakwale, S. (2004). The impact of the introduction of futures contracts on the spot market volatility: the case of Kuala Lumpur Stock Exchange. Applied Financial Economics, 14(2), 143-154.

Pilar, C., \& Rafael, S. (2002). Does derivatives trading destabilize the underlying assets? Evidence from the Spanish stock market. Applied Economics Letters, 9(2), 107-110.

Ross, S.A., 1989, Information and volatility: The no-arbitrage martingale approach to timing and resolution irrelevancy, Journal of Finance 44, 1-17.

Ryoo, H. J., \& Smith, G. (2004). The impact of stock index futures on the Korean stock market. Applied Financial Economics, 14(4), 243-251.

Santoni, G. J. (1987, May): "Has Programmed Trading Made Stock Prices More Volatile?," Federal Reserve Bank of St. Louis Review, 18-2

Stein,J.C., 1987, Informational externalities and welfare-reducing speculation, Journal of Political Economy 95, 1123-1145.

Stoll, H., and Whaley, R. (1987). Program Trading and Expiration-Day Effects. Financial Analysts Journal, 43:16-27

Stoll, H. R., \& Whaley, R. E. (1997). Expiration - Day Effects of the All Ordinaries Share Price Index Futures: Empirical Evidence and Alternative Settlement Procedures. Australian Journal of Management, 22(2), 139-174.

Swidler, S., Schwartz, L., \& Kristiansen, R. (1994). Option expiration day effects in small markets: Evidence from the Oslo Stock Exchange. Available at SSRN 5375.

Yadav, P. K., \& Pope, P. F. (1994). Stock index futures mispricing: profit opportunities or risk premia?. Journal of Banking \& Finance, 18(5), 921-953. 